\title{
Socio-economic and political responses to regional polarisation and socio-spatial peripheralisation in Central and Eastern Europe: a research agenda
}

\author{
ThILO LANG ${ }^{1}$
}

\begin{abstract}
In the past years, new patterns of regional disparities between metropolised core regions and the remaining parts of Central and Eastern European countries (CEE) have emerged. Such spatial disparities have lately fuelled concerns about further regional polarisation and the peripheralisation of non-metropolitan regions in particular. This is the case although balancing spatial development has been a major goal of European Regional Policy. The paper argues that there is a clear need to better understand the social, economic, discursive and political processes constituting regional polarisation and to conduct further research on approaches to deal with and respond to peripheralisation. The proposed research agenda focuses on a multi-scalar relation between core and peripheral regions and applies a process based dynamic understanding of peripherality and centrality. Following this, peripheralised regions bear agency capacities and cannot be seen as powerless victims of some overarching processes associated with the globalising economy. Applying the notions of polarisation and peripheralisation to guide further research, offers multi-dimensional, multi-scalar and process based conceptualisations of regional development research. With the proposed research agenda, I would like to open up the discussion on new interpretations of the terms peripherality and centrality, rurality and urbanity, border and rural areas, core and peripheral regions, and contribute to the development of new approaches in multi-level governance and ultimately in regional policy.
\end{abstract}

Keywords: territorial cohesion, regional policy, spatial disparities, uneven development, peripheralisation, polarisation

\section{Introduction}

In the past $10-15$ years new forms of disparities have emerged in Central and Eastern Europe (CEE) but remained largely unnoticed by both the public and scientists in geography and regional studies: a strong socio-economic spatial polarisation between metropolised core regions and the remaining parts of the CEE countries (KRÄTKE, S. 2007; Dubois, A. et al. 2007; LANG, T. 2011). Such disparities have not only become a striking feature of the current settlement system but in the face of the ongoing economic, financial and national debt crisis have fuelled concerns about further polarisation and the peripheralisation of non-metropolitan regions. It is striking that we can observe these processes and discourses although balancing spatial development to achieve territorial cohesion has been a major goal of European Regional Policy in the past years (EU 2011). As such, patterns of increasing socio-economic disparities combined with regional polarisation do not remain restricted to $\mathrm{CEE}$, but rather can be found throughout the European Union and beyond, albeit at different degrees.

Against this background, there is a clear need to:

(1) better understand the social, economic, discursive and political processes constituting regional polarisation and interrelated policymaking processes in different contexts,

\footnotetext{
${ }^{1}$ Leibniz-Institut für Länderkunde, Schongauerstr. 9, 04328 Leipzig, Germany. E-mail: T_Lang@ifl-leipzig.de
} 
(2) produce better knowledge on different disciplinary and cultural planning and policy traditions in the EU,

(3) communicate relevant information and improve multi-agent decision making for regional policy under uncertain framework conditions.

To achieve this, this paper proposes to enhance research on socio-economic forms of and processes interlinked with regional polarisation and perpiheralisation, their wider impacts on society and everyday living as well as the (intentional and unintentional) responses and strategies conveyed by social, economic and political actors as well as 'ordinary people' in order to better deal with these phenomena. This includes research on (discursive and material) practices of the production and reproduction of peripherality and centrality as well as the logics of responses at multiple scales. With such a research agenda, a network of regional development experts throughout Europe suggests to respond to new patterns of regional disparities in CEE and beyond. ${ }^{2}$

Following this introduction, I briefly outline some empirical observations about socio-spatial polarisation in CEE and depict four main gaps in research on socio-spatial polarisation and issues of regional policy in Europe. Section two introduces polarisation and peripheralisation as analytical concepts. The following three sections are outlining propositions for further research in three interconnected fields:

- evolution, reproduction and persistence of centrality and peripherality,

- governance of core-periphery relations and

- adaptation, strategies and potentials.

\footnotetext{
${ }^{2}$ The research leading to these results was conducted in the frame of the project "Socio-economic and Political Responses to Regional Polarisation in Central and Eastern Europe" (RegPol$\left.{ }^{2}\right)$, coordinated by the Leibniz Institute for Regional Geography, Leipzig/Germany. The project received funding from the People Programme (Marie Curie Actions) of the European Union's Seventh Framework Programme FP7/2007-2013/ under REA grant agreement no. 607022.
}

\section{Some empirical observations and current shortcomings in polarisation research}

CEE countries currently show strong evidence for three main spatial development characteristics (Komornicki, T. and Czapiewski, K. 2006): First, there are profound differences in development between urban core regions and peripheral rural regions with the urban regions performing much better. Second, these countries demonstrate strong trends towards polarisation between their main metropolitan area (usually the national capital) and the rest of the country, and third, an east-west-gradient can often be found within the countries with the western parts performing better than their eastern regions. As a consequence of these developments, today only one or a few strong economic 'engines' stand out against a growing number of regions with low economic dynamics which become perceived as less attractive locations for people and business. Thereby the sharp increase of regional disparities stands against the diminishing socio-economic differences between old and new member states on the national level (Finka, M. 2007; Monfort, P. 2009; Chilla, T. and Neufeld, M. 2015).

As a result, already existent patterns of regional polarisation have experienced a strong intensification in recent years (GorzelaK, G. and $\mathrm{GoH}, \mathrm{C}$. 2010), resulting in disproportionally high increases of regional disparities in the CEE countries compared to the EU15 states, measured e.g. in GDP-data (Figure 1) or in unemployment data (see Dubois, A. et al. 2007; Artelaris, P. et al. 2010; LANG, T. 2016; for the critics see Openshaw, S. 1984; for alternative measurements see e.g. Perrons, D. 2012; OECD 2014).

Parallel with the growing concentration of economic activities in metropolitan areas current demographic developments further exacerbate problems of deepening polarisation (Filipov, D. and Dorbritz, J. 2003; Steinführer, A. and HaAse, A. 2007). CEE population is increasingly concentrated in a diminishing number of prosperous areas, particularly the capital regions, in contrast 


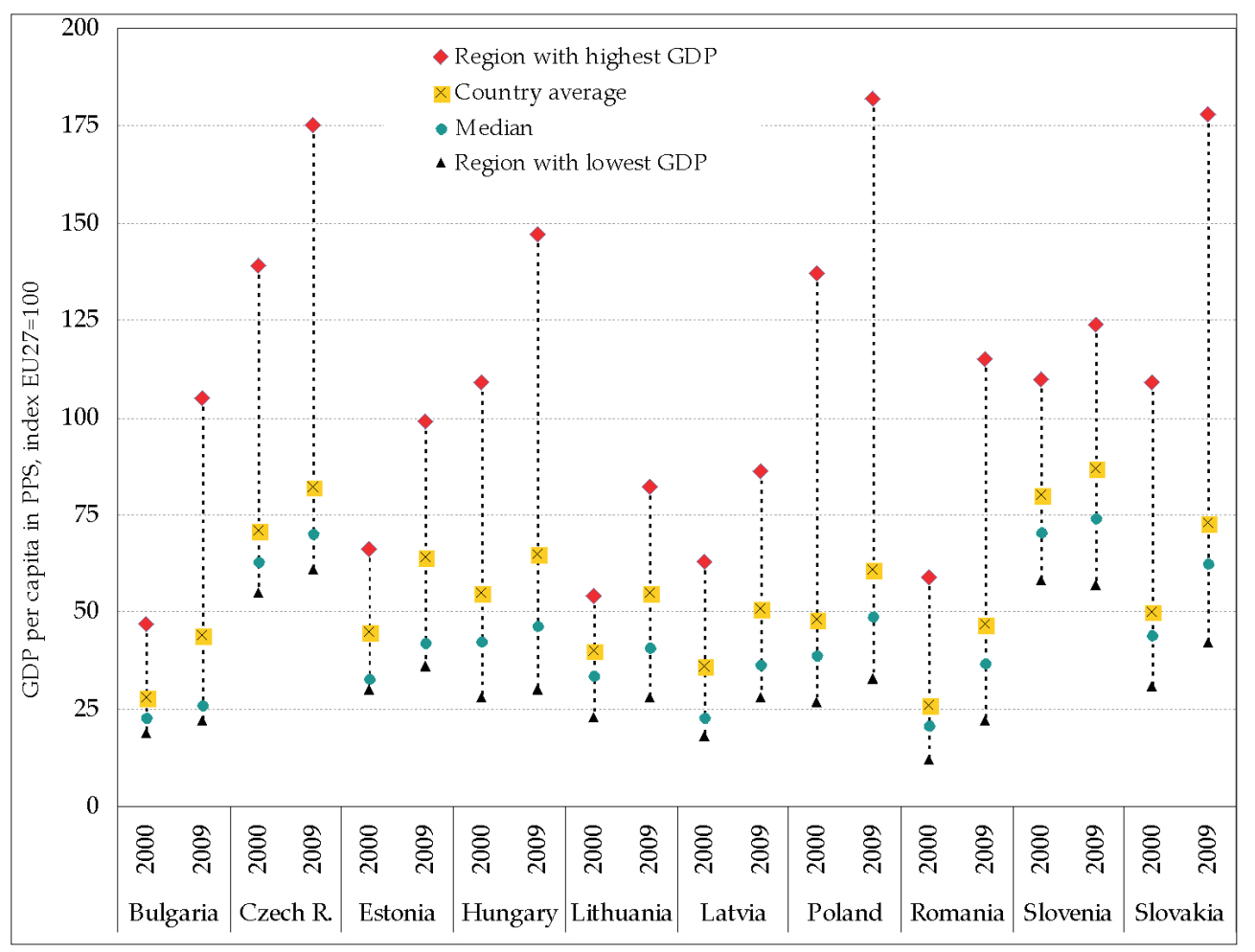

Fig. 1. Increase of regional polarisation in GDP per capita, NUTS-3 regions 2000 and 2009 (calculated by Tomas Hanell and Stefan Haunstein, data source: Eurostat)

to a growing number of regions suffering population decline. Thereby intra- and inter-regional migration patterns overlap with international migration on the basis of age-selectivity, stratified labour mobility and an overall decline of birth rates which is particularly sharp in CEE. The decrease in population has been particularly pronounced in structurally disadvantaged rural and deindustrialised regions as well as many inner-city and high-rise, edge of city areas (Tsenkova, S. 2006; STEINFüHRER, A. and HaAse, A. 2007). These demographic developments combine with other processes of social differentiation to produce highly uneven social geographies at regional, sub-regional, intra-urban, and micro-geographic scales that intersect but do not necessarily overlap (see also PoSCoPP 2015).

Looking at forms of peripheralisation at a global scale, it is notable that CEE re- gions play a negligible role when world city hierarchies are analysed, such as by the 'Globalisation and World Cities Research Network' (GaWC) focussing on financial services and number of specific globalisation indicators (only Moscow and Warsaw are recognised as Command and Control Centers and as Alpha World Cities (Сsomós, G. and Derudder, B. 2014; Parnreiter, C. 2014). Following Friedmann's and SAssen's work on the world or global city (FrIEDMANN, J. 1986; SAsSEN, S. 1991), a number of authors have argued that worldwide economic activities have become concentrated in a small number of city-regions. In the globalised economy, only a few global cities and metropolitan regions are said to be the 'control points of the global economic system' (BeAverstock, J.V. et al. 2000).

One could argue that CEE cities and their functional regions are being peripheralised 
by the dominance of world cities in the global economy. European and national policies add a further dimension to this, as they frequently copy the model of the global city in regional policies by focusing on the promotion of growth in metropolitan areas (BRENNER, N. 2009). So far, also European regional policy programmes and the introduction of new forms of regional governance did not help to achieve more balanced spatial development and to distribute development impetus more evenly across CEE regions. This has been witnessed particularly in the aftermath of the most recent financial and economic crisis, as decision makers have been led to concentrate scarce resources on supporting development in larger cities, hoping that disadvantaged areas will profit from core-periphery spillover effects. Such policies, however, carry a major risk of further increasing socio-spatial polarisations and the peripheralisation of disadvantaged areas (for example due to disinvestment in transport infrastructures or centralisation of service provision).

In addition, in CEE prevailing negative experiences from the period of centrally planned economies have led to a sceptical perception of public sector interventions and to a general turn towards neoliberal policies during the transition period (Bohle, D. 2006; Aligica, P.D. and Evans, A. 2009). This has to be seen in relation to both, uneven power relations in the context of supra-nationally imposed institutional reforms and the active involvement of East European reformers who were adherents of neo-liberalism even before 1989. Reviewing very recent changes in European policy debates, some authors have claimed that regional policy in the EU has become more neoliberal to the extent of distributive and cohesion aspects of regional policy (Avdikos, V. and Chardas, A. 2015) making a reduction of disparities in the next years less likely.

Despite the long research tradition in geography, regional economy, political science and urban planning, and even though coreperiphery relations have been studied at global, national, regional and urban levels, the research on regional polarisation processes up to now has been characterised by four major shortcomings:

- So far the main focus has been on quantitative, regionally limited studies. Only to some extent they do raise issues of interdependencies with phenomena and institutional contexts outside the respective regions, and by trend sparsely question regional socio-economic and policy responses and their normative dimensions. Further, most quantitative studies on polarisation work with GDP and population development indicators which cannot capture the multi-dimensional complexity of the phenomena under consideration.

- The social construction of core-periphery relations has been reviewed only to a small degree, especially in the CEE context (e.g. Timár, J. et al. 2012; EhrLich, K. et al. 2012). There is a clear need for a better knowledge about predominant discourses and paradigmatic backgrounds of European, national and regional policies in particular.

- Most polarisation and cohesion research ignores the overlapping nature of core-periphery relations at regional, national, European and global levels (Sellers, J.M. 2002a). Researching the multi-level characteristics of socio-spatial development is in particular relevant for CEE countries which underwent a rapid exposure to processes of globalisation and internationalisation after the political changes in the early 1990s and even more so after their accession to the EU.

- Moreover, the formation of regional policies at the national level in CEE is still in its early stage (FINKA, M. 2011) and there is too little known about the ways, how regional policy responses and new forms of governance have emerged in CEE during the last years and how they inter-relate with other forms of local and regional response.

\section{Polarisation and peripheralisation as analytical concepts}

The observations summarised above show that various processes lead to and interlink with socio-spatial polarisation at different in- 
tersecting scales. Also apparent, however, is the need to look critically at our approaches to researching these phenomena and processes and to consider how and why different insights are produced from different perspectives. Thus, while helpful for the identification and assessment of the scope and reach of socio-economic regional polarisation, conventional indicators ${ }^{3}$ rarely capture the wide range of causes and dimensions of polarisation as a process that intersects with other aspects of inequality, uneven development and power breaching conventional territorial boundaries (see also Perrons, D. 2012).

I suggest understanding polarisation and peripheralisation as analytical concepts that facilitate process-based relational understandings of spatial differentiation and supplement structural research approaches (see also Massey, D. 2009; Varró, K. and LAGENDijK, A. 2013). Although our focus lies on the regional scale I suggest a multi-level conceptualisation of the phenomena under observation. As the relation of core and periphery is immanent to the concept, peripheralisation implies processes of centralisation and thus forms of socio-spatial polarisation at various scales. Such forms of polarisation are intrinsically connected to the discourse which places higher value on particular regions and developments and thereby devalues others. Some authors define regional peripheralisation as the growing dependence of disadvantaged regions on the centre (e.g. Komlosy, A. 1988); hence, it is not only the simultaneity of a number of features constituting the formation of peripheries such as distance, economic weakness and lack of political power (cf. Blowers, A. and Leroy, P. 1994). It is often also the dynamic formation of core and peripheral regions overlapping at different spatial scales (regional, national, European and global). This multi-faceted, multi-level understanding of polarisation has the potential to identify novel starting points

\footnotetext{
${ }^{3}$ Such as rates of inward investment, GDP growth, availability of key infrastructures and services, distance from metropolitan cores, or poor accessibility.
}

for research on current regional development issues. Applying these conceptual notions offers opportunities for spatial research circumventing dichotomous ideas of urban and rural, of central and peripheral, of 'leading' and 'lagging' or growing and declining which tend to determine our methodological, theoretical and normative approaches to regional studies.

In Central and Eastern Europe, focusing on processes of polarisation provides an important starting point for critical analyses of the assumptions on which the Washington Consensus of the early 1990s was built, such as the claim that radical privatisation and the swift introduction of unimpeded marketeconomies would right the wrongs of statesocialism most effectively and would (eventually) deliver prosperity to, if not all, then at least a majority of people. What we have witnessed since is a much more diverse and problematic picture: whilst in terms of GDP growth, many parts of the macro region - in particular the capital regions - have indeed embarked on an upward trajectory after the initial crisis of the early 1990s, the success of market reforms to improve living standards and to ensure a more even spread of wealth amongst wider populations has been limited (Sмith, A. et al. 2008; Sмith, A. and Timár, J. 2010; Stenning, A. et al. 2010).

Up until recently, spatial development in CEE has mainly been researched through the lenses of post-socialist transformation and modernisation tending to perceive all processes in CEE as being quite particular and closing up comparative perspectives in relation to similar processes outside of CEE. This has also led to a limited research interest in inter-scalar relations and tended to favour internal reasons and innate properties as explanations for problems in social, economic and spatial development. Acknowledging socialism and post-socialism as being part of CEE history but adding alternative approaches (such as those being based on the notions of peripheralisation and polarisation) enables new comparative perspectives to similar phenomena in other parts of Europe and the 
world and also helps to better conceptualise the role of super-ordinate processes and forces with impacts on CEE regions. This is particularly true since the 2007-2008 economic, financial and national debt crisis has shown similar economic, social and spatial impacts as well as political forms of response across Europe as a whole.

Following the outlined understanding of peripheralisation and polarisation, it is suggested to build up a research agenda based on five axioms:

(1) Socio-spatial polarisation should be seen as a multi-level, multi-dimensional process which is an intrinsic part of current capitalism and dominant market-logics. However, there is more and more empirically based research claiming that a socially and spatially more even society would also produce more growth (e.g. Piketty, T. 2013; OECD 2014 and 2015), adding an economic to the social argument for state intervention and regulation as well as a form of regional policy that maintains the distribution goal. Nevertheless, problematising particular forms and impacts of socio-spatial polarisation and defining urban and regional development keeps to be a social process (cf. PIKE, A. et al. 2007) and depends on what is seen as normal, acceptable or achievable in a societal discourse.

(2) Peripheries are made through material and immaterial processes and practices of peripheralisation and centralisation. It is these processes and practices which should be given more focus in social science based spatial research. All sorts of actors have their (implicit and explicit) shares in these processes, hence peripheralised regions cannot be seen as victims of some overarching processes beyond their control without any agency to them. Neither peripheries nor centres can be seen as static concepts with naturally given features and boundaries. Peripheralisation and centralisation are dynamic processes which can be reversed, rejected or redirected in the long run. Hence, when researching regional polarisation, we should direct our interest to these dynamic processes instead of static concepts of core and periphery.
(3) Urban and regional policy is always normative (even if its arguments are based on empirical data) and framed by individual and collective values linked to specific understandings and conceptualisations of development, desired policy outcomes and funding priorities. Such understandings, conceptualisations and priorities can be seen as the results of discourses linked to particular governance arrangements which are only partly state-led. The perceptions of acceptable and achievable forms of socio-spatial development are socially constructed and can only to a small extent be seen as the outcome of a rational process. Exactly for this reason, decision making and governance are constrained and shaped through specific institutional environments privileging and devaluing certain forms of action - certainly limiting the local and regional room for manoeuvre.

(4) There are similar - often overlooked - constraints in economic development and with regard to activities of economic agents: the economy is a social construct and can only partially be explained in terms of rational decision making; economic decisions are social decisions and reflect wider institutional and discursive constraints.

(5) Studying migration and mobility in the context of polarisation research is incomplete if it only captures quantitative processes without going deeper to conceptualise relations, motives and the circumstances of migration decisions. Migration should be seen as a (often temporary) result of subjective decisions in a household, family or social context based on personal and collective environments linked to particular place-specific values (in some cases we can talk about emigration cultures or a particular modus agendi inscribed to the institutional environment, see LANG, T. 2012a,b).

Following this conceptual argumentation, I suggest to focus future polarisation research on three objectives:

- to better understand the evolution, (re-) production and persistence of core-periphery relations using a dynamic conceptualisation of these relations, 
- to identify and compare policy responses (and subsequent governance arrangements) to regional polarisation at different scales and understand how they emerged,

- to identify patterns of adaptation and resistance as well as strategies and potentials to overcome peripheralisation.

\section{Evolution, reproduction and persistence of centrality and peripherality}

The evolution of core and peripheral regions does not follow any 'natural' order. Instead, centrality, peripherality and their interrelation are produced and constantly reproduced by social interaction, territorial mobility, political and economic decisions (Blowers, A. and Leroy, P. 1994; Nagy, E. et al. 2015). Although regional polarisation in this respect can change over time, the underlying structures are very persistent and tend to reproduce themselves (GidDENs, A. 1993) - changes are thus rather an issue of generations and less likely to occur in short terms. Further research should consider how the perception of location (dis)advantages, migration and demographic developments as well as particular policies have contributed to the evolution, reproduction and persistence of centrality and peripherality and regional polarisation.

We could learn a lot about the formation of regional disparities and in particular about the emergence and persistence of peripheralities by looking at processes of centralisation and how the intentional and unintentional concentration of resources in and positive ascriptions to particular privileged places is to the disadvantage of other places. Research on the evolution, reproduction and persistence of disparities should also deal with the question of how core and peripheral areas are socially constructed in a multi-scalar way.

A number of studies explore the discursive relationships between economic centres and peripheries and argue that peripheralisation is a process which is strongly linked to how some spaces are represented by economic centres (MASSEY, D. 1993; JANSSON, D. 2003; ERIKSSON, M. 2008; WilletT, J. 2010) but also from within peripheralised places themselves (Miggelbrink, J. and Meyer, F. 2015). Here, peripheries can find themselves described in ways that reinforce dependency through being characterised as 'stagnant', 'backward', 'rural' and agents of their own economic misfortune. Such dominant discourses can lead to collective orientations hindering local economic development e.g. by increasing emigration (BeEtz, S. 2009; LANG, T. 2012b) or through a reluctance of 'core' businesses to work with peripheral organisations (Bosworth, G. and Willett, J. 2011).

It is in particular individual and collective perceptions, ideas and values that shape spatial policies, economic and household decisions - all of which contribute (by means of their material consequences) to the production and persistence of centrality and peripherality. Perceptions, ideas and values about and ascribed to a thing (or region) are constructed through formations of power. Such 'knowledge' is replicated through discourse by individuals, organisations and institutions. These affect how a place is perceived by others, placing limitations (or expectations) on what people and organisations are imagined capable of (ErIKssON, M. 2008; Bosworth, G. and Willett, J. 2011). This is an 'othering' process, whereby one region is presented as qualitatively 'different' to another, and which mirrors contemporary regional development, whereby regions are encouraged to distinguish themselves from others in order to better compete in the global market (KeAting, M. 2008).

As despite all policy efforts, regional polarisation increased during the past years, we cannot be sure, if current sectoral and spatial policies help to reduce or rather reproduce peripheralisation and polarisation. To what extent do these policies reduce, reproduce or even reinforce existing centralities and peripheralities and to what extent can this be traced in new spatial instruments (such as metropolitan regions, cf. Allmendinger, P. et al. 2015; see also RAAgmAA, G. 2015; FINKA, 
M. et al. 2015). In particular economic policy in Europe is said to have followed neoliberal logics, thereby concentrating resources to a smaller number of places and furthering polarisation (e.g. Avdikos, V. and Chardas, A. 2015). Thus, it is relevant to raise the question to what extent this holds true for European, national and sub-national policies. Moreover, how broad is the current toolbox for regional economic policy within the EU and how are alternative ideas of development contested?

And finally, how do locally active decision makers, economic agents and ordinary people contribute to the emergence, persistence and reproduction of centralities and peripheralities? In particular with regard to economic and migration decisions, there is a need to better understand how the interactions of 'peripheral' agents with 'core' actors and their embeddedness into various local and non-local networks reflect, reproduce or counteract centrality and peripherality. What kind of spatial perceptions and relations do influence regional mobility and investment decisions? And to what extent do these decisions constitute and reproduce such perceptions and relations?

\section{Governance of core-periphery relations}

For many authors, processes of and responses to peripheralisation are linked to issues of governance (e.g. RAAGmAA, G. 2015). Following the above outlined conceptualisation, governance research with regard to the development of peripheralised regions bears three major shortcomings: (1) instead of looking at territorially limited governance networks, a multi-directional perspective on core-periphery relations should be included; (2) the role of normative frames for the ways regional and economic policies are implemented is under-researched; (3) within governance-research, the role of single charismatic leaders is often overlooked. In general, however, the role of governance is often overestimated compared to other factors influencing local and regional development.
Although, with the Territorial Agenda 2020, the EU has been following the concept of territorial cohesion since 2010, there has been little research about the (national, regional, local) implementation of policy responses to intensifying regional polarisation. Further, regional development and planning policy in the new member states also reflects a particular turn towards neoliberal policies. "In these countries, the fragility of the planning systems following the breakdown of socialistinfluenced structures led to a particular willingness to accept market economy and rather neoliberal tendencies" (REIMER, M. et al. 2014. p. 8). This coincides with a more general neoliberal shift in public service provision, public government and policies being catalysed through processes of "Europeanisation" (WATERHout, B. et al. 2013).

There is a tendency at EU-level, that issues of balanced spatial development and territorial cohesion are de-prioritised and replaced by the logic of competitiveness, place-based development and growth-based concentration (Avdikos, V. and Chardas, A. 2015). We could argue with SERvillo that through discursive chains, these strategic concepts become hegemonic, making other ways of thinking, other 'rationales' and policy options marginal (SERvillo, L. 2010; see also WATERHOUt, B. et al. 2013. p. 144) and leading to particular ways and forms of how coreperiphery relations are governed. In this context, policies favouring the concentration of resources are on the rise at national and supranational level in Europe and beyond.

Some authors would see this as being linked to a process of Europeanisation through transnational learning and policy transfer (Dolowitz, D.P. and MARSH, D. 2002; Bulmer, S. and Padgett, S. 2005). It is suggested to perceive this process as being part of a more general shift towards neoliberal development concepts in the fate of the globalisation debate and a general global trend favouring the big cities as economic engines and attractive places to work and live in as a specific preference of the current capitalist society (see also KRÄTKE, S. 2007; WATERHOUT, 
B. et al. 2013). It is in this context that we should analyse next to the emergence, the institutionalisation and implementation of regional policies and various forms of public interventions applying concepts of governance, path renewal and leadership.

The term 'governance' bears normative, theoretical and methodological dimensions (StOKeR, G. 1998). This makes it necessary to entangle the different discourses around the concept of governance and to develop sound theoretical foundations to improve transnational comparative research on the governance of core-periphery relations. It is proposed to understand governance as a heterarchical, cross-sectoral, multi-level arena for decision making which works in specific, relatively stable network-type arrangements. When researching policy responses to polarisation and peripheralisation we should be cautious not to overlook the role of normative frames in formulating policies. To what kind of frameworks do actors refer to when they argue for particular forms of policy intervention? Which concrete planning instruments are used to achieve a more balanced development at regional level and what are the preconditions for successful collaboration within fragmented regions? Up to now only little is known about the conditions which allow for successful cooperation between actors from core and peripheralised areas that aim at balancing out regional disparities.

As differences in the economic structure of regions are often seen as one reason for increasing spatial polarisation, I suggest a particular research focus on the governance of economic development. Although there has been a lot of research on the problems of old industrial regions, still little is known about how urban and regional economies change and how this change can be governed in a positive way. What can we learn from governance attempts in successful new economy locations? How big (or minor) is the role of economic governance at all? Originating in institutional and evolutionary economics, the concept of path dependence has also been transferred to political sciences (PIERson, P.
2000) and provides an important theoretical starting point for such types of research. It creates an opportunity to understand factors shaping urban and regional policy responses in old and new economy locations and to identify the actions and practices that may alter the current path and set the regions on new development trajectories (path renewal, Coenen, L. et al. 2015).

One attempt to explain differences in how localities and regions with very similar socio-economic challenges manage to regenerate is to analyse the role public leaders play (Sotarauta, M. et al. 2012). We know, how specific institutional environments limit the local room for manoeuvre (LANG, T. 2009). Nevertheless, we know little about to what extent charismatic leaders can promote institutional change and develop adaptive capacities (NorTH, D.C. 1990) to open up new development trajectories in localities with severe social and economic problems. The impact of leadership on these forms of change so far is clearly under-researched.

\section{Adaptation, strategies and potentials in peripheralised non-metropolitan areas}

Although often receiving only marginal attention in national development strategies, non-metropolitan, rural and peripheral areas are home to almost half of the European population, bear major spatial functions and in many cases play a decisive role in political, social and economic innovation processes (McCANN, E.J. 2004; McCARTHY, J. 2005).

Questioning current paradigms which regard the city (and in particular the metropolis) as the major centre for social, economic and political innovation, non-metropolitan areas should also be considered as arenas within which future development perspectives arise (SHEARMur, R. 2012). However, peripheralised places are often conceptualised as powerless and passive victims of some superordinate processes beyond their control. This position often makes us overlook the varied dimensions of agency and strategic 
action linked to 'peripheral' actors. These forms of agency can range from social interaction reproducing existing core-periphery relations to specific forms of adaptation or even resistance to dominant representations. With a focus on adaptation, strategies and potentials, It is suggested to conduct more research on (the sometimes hidden) phenomena relying on local resources.

LAclau's and Mouffe's reworking of hegemony explores how the 'powerless' can propagate alternative forms of knowledge through networks and cooperation, challenging dominant representations (LACLAU, E. and Moufre, C. 1985). When applied to regional development, this indicates that the 'knowledge' within representations of place has particular effects, and that this knowledge undergoes processes of change and rearticulation. Instead of perceiving uneven power-relationships as something fixed, a more satisfactory analysis would explore the multi-dimensional aspects of power through mechanisms such as hegemony. Here, peripheries are not passive recipients of damaging 'backward' and 'stagnant' types of representation, but play an active role in the discursive process. This leads to questions about 'peripheral' strategies of reworking or resisting dominant representations (ERIKSSON, M. 2008) and opens up possibilities for a multiscale conception of centrality and peripherality (Sellers, J.M. 2002a,b; McCanN, E.J. 2004; Hudson, R. 2004, 2005).

Against this background, household practices as well as innovative activities from civil society and businesses in peripheralised spatial settings could be analysed regarding their potential for new forms of regional development and bottom-up social, economic and policy change. To what extent do 'ordinary' people organise their life under the conditions of peripheralisation? In what way do they rework, reproduce or resist dominant processes of peripheralisation? What kind of (alternative) futures do they aim for through every day practices? Key tasks could be to analyse households' changing experiences and perceptions of socio-spatial polarisation, and to explore how they overcome existing core-periphery disparities.

We should also link a number of alternative economic approaches to the household scale which stress locally rooted and embedded forms of economic activity. One example for such an approach discussed as a source for alternative economic development in rural areas is the renewable energies sector (biomass, wind, solar energy). Although in general there is a considerable job effect of renewable energy activities (and other 'alternative' and 'new' forms of economic activities) throughout Europe, it is quite unclear to what extent local communities can benefit from such activities. Hence, I suggest to differentiate community driven from externally driven initiatives. In so doing, we could conceptualise these activities acknowledging their direct local and social impact. Locally owned projects would guarantee that revenues stay in the region and also that key entrepreneurial aspects could be negotiated locally. Research could, thus, focus on the role of local potentials and resources and the ways policy makers aim at boosting life satisfaction, the living standard and to promote local and regional development.

For regions with severe social problems, also the social economy has often been seen as a normative solution. However, empirical research has concluded that the economic impact of social economy activities has mainly been symbolic (AмiN, A. et al. 2002. p. 116, 125). In particular when it comes to newer forms of social innovation and more recent attempts to re-invent the social economy, there is scope for more research on the role of social economy initiatives in non-metropolitan regions (EHRLICH, K. and LANG, T. 2012). There are two main themes for future research in this respect: first, there should be a focus on the individual and collective drivers of a new generation of social enterprises working more and more independent from state benefits, and second, the role of the state should be carefully examined as supporting the social economy has also become a state strategy to compensate for its 
withdrawal from public service provision in peripheralised areas.

Researching innovation in the formal economy in non-metropolitan regions, should start with reviewing the more recent literature on knowledge and innovation (BATHELT, H. and GLÜCKLER, J. 2011), on different types of knowledge transfer (e.g. Boschma, R. 2005) as well as on critical network theory perspectives (GlücKLER, J. 2013). The inclusion in global networks of information flows and production chains as well as the various ways to generate innovations are completely under-researched when it comes to entrepreneurial activities in peripheral regions (as exceptions: VirkKala, S. 2007; LAgENDijk, A. and LorentZen, A. 2007), but these aspects bear the potential to challenge dominant perceptions of the relation between the economy and space. This is all the more important since innovation can contribute to both an increased regional polarisation and a balance between core and peripheral regions. With a less normative perspective on the relation between innovation and space, policy makers will be better able to identify and utilise the economic potentials and opportunities of their regions and to promote change from an entrepreneurial bottom-up perspective.

\section{Conclusions}

Although the European Union has been following regional and cohesion policies for years and stressed the objective to achieve balanced spatial development and territorial cohesion with the Territorial Agenda, regional socio-spatial polarisation increased in the past years. In particular in Central and Eastern Europe (CEE), there is a risk that spatial development further concentrates in a smaller number of (metropolitan) regions whereas more and more other regions might be affected by processes of peripheralisation. In this context, I believe it is timely to conduct further research on the relevant issues of regional polarisation and peripheralisation with a strong focus on CEE.
So far, regional development research has been interested either in 'winning' core regions, or in shrinking, declining or peripheralised rural, non-metropolitan or old industrial regions. By contrast, the proposed research agenda focuses on the relation between cores and peripheries (respectively processes of centralisation and peripheralisation), a process based conceptualisation of the issues to be researched and an understanding of peripheralised regions with agency capacities instead of being perceived as powerless victims of some overarching processes beyond control. Peripherality and centrality should be perceived as revisable characteristics and as socially, culturally or discursively constructed.

Applying the notions of polarisation and peripheralisation offers multi-dimensional, multi-scalar and process based conceptualisations of regional development research which are under-represented in European urban and regional studies. With the proposed research agenda, I would like to open up the discussion on new interpretations of the terms peripherality and centrality, rurality and urbanity, border and rural areas, core and peripheral regions, and contribute to the development of new approaches in multi-level governance and ultimately in regional policy.

While research on polarisation up to now has focused on a specific spatial level (mostly the region itself), I suggest to approach spatial relations from a multi-level perspective by looking at the interplay of local, regional, national and international contexts, structures and processes which affect socio-spatial polarisation. Thereby, I stress the need to tackle these issues in a multi-method and multi-disciplinary approach open to diverse conceptual backgrounds of all researchers in urban and regional studies following this agenda. I strongly believe that each disciplinary and methodological perspective has its contribution in this field. There is no ultimate truth which can be proven by any kind of (quantitative or qualitative) data. Hence, the proposed research agenda is meant to add to existing studies and should be seen as an 
invitation to think differently about the phenomena each of us is going to research.

We do hope, the proposed research agenda will produce a more complete picture of perceptions, processes and understandings of regional polarisation and socio-spatial peripheralisation in CEE and beyond. I have highlighted so far under-researched issues of the evolution, reproduction and persistence of centrality and peripherality, issues linked to the governance of core-periphery relations and some aspects which might bear potentials for alternative forms of development and de-peripheralisation. This might also invite others to tackle research questions linked to achieving better futures for peripheralised regions and improving the information base for political decision making under the conditions of polarisation and peripheralisation as complex, multi-dimensional and multi-scalar socio-spatial phenomena.

Acknowledgements: The author thanks the following colleagues who have contributed to the underlying thoughts and discussions and for their helpful comments on earlier drafts of this paper: József Benedek, Maros Finka, Tomas Hanell, Sebastian Henn, Kathrin Hörschelmann, Zoltán Kovács, Judith Miggelbrink, Erika NagY, Garri RaagmaA and Judit Timár.

\section{REFERENCES}

Aligica, P.D. and Evans, A. 2009. The neoliberal revolution in Eastern Europe. Economic Ideas in the Transition from Communism. Cheltenham, Edward Elgar Publishing Limited.

Allmendinger, P., Haughton, G., Knieling, J. and Othengrafen, F. (eds.) 2015. Soft Spaces in Europe. Re-negotiating governance, boundaries and borders. Abingdon, Routledge.

Amin, A., Cameron, A. and Hudson, R. 2002. Placing the Social Economy. London, Routledge.

Artelaris, P., Kallioras, D. and Petrakos, G. 2010. Regional inequalities and convergence clubs in the European Union New Member States. Department of Planning and Regional Development Discussion Paper Series 16. (3): 43-62.

Avdikos, V. and Chardas, A. 2015. European Union Cohesion Policy Post 2014: More (Place-Based and Conditional) Growth - Less Redistribution and Cohesion. Territory, Politics, Governance. Available from: doi:10.1080/21622671.2014.992460 [Accessed 9 June 2015].

Bathelt, H. and GlüCKLer, J. 2011. The relational economy. Geographies of knowing and learning. Oxford, Oxford University Press.

Beaverstock, J.V., Smith, R.G. and Taylor, P.J. 2000. World-City Network: A New Metageography?. Annals of the Association of American Geographers 90. (1): 123-134.

BeEtz, S. 2009. Analysen zum Entscheidungsprozess Jugendlicher zwischen "Gehen und Bleiben". Die Relevanz kollektiver Orientierungen bei Migrationsentscheidungen ostdeutscher Jugendlicher. In Regionale Abwanderung Jugendlicher. Theoretische Analysen, empirisiche Befunde, und politische Gegenstrategien. Eds.: SCHubarth, W. and SPECK, K. Weinheim, Juventa Verlag, 135-151.

Blowers, A. and Leroy, P. 1994. Power, politics and environmental inequality: A theoretical and empirical analysis of the process of 'peripheralisation'. Environmental Politics 3. (2): 197-228.

Bohle, D. 2006. Neoliberal Hegemony, Transnational Capital and the Terms of the EU's Eastward Expansion. Capital \& Class 30. 57-86.

Boschma, R. 2005. Proximity and innovation: a critical assessment. Regional Studies 39. (1): 61-74.

Bosworth, G. and Willett, J. 2011. Embeddedness or Escapism? Rural Perceptions and Economic Development in Cornwall and Northumberland. Sociologia Ruralis 51. (2): 195-214.

BrenNer, N. 2009. What is critical urban theory? City: analysis of urban trends, culture, theory, policy, action 13. (2-3): 198-207.

Bulmer, S. and Padgett, S. 2005. Policy Transfer in the European Union: An Institutionalist Perspective. British Journal of Political Science 35. (1): 103-126.

Chilla, T. and Neufeld, M. 2015. Cohesion as a multi-scalar challenge: The EU-wide perspective. In Understanding Geographies of Polarization and Peripheralization. Eds.: Lang, T., Henn, S., Ehrlich, K. and Sgibnev, W. Basingstoke, Palgrave, 199-2016.

Coenen, L., Moodysson, J. and Martin, H. 2015. Path renewal in old industrial regions: possibilities and limitations for regional innovation policy. Regional Studies 49. (5): 850-865.

Csomós, G. and Derudder, B. 2014. European cities as command and control centres, 2006-11. European Urban and Regional Studies 21. (3): 345-352.

Dolowitz, D.P. and MARsh, D. 2002. Learning from Abroad. The role of policy transfer in contemporary policy-making. Governance 13. (1): 5-23.

Duвогs, A. et al. 2007. Regional Disparities and Cohesion: What Strategies for the Future? Report to the Directorate General Internal Policies of the Union. [Online] Brussels, European Parliament. Available from: http://www.europarl.europa.eu/hear- 
ings/20070625/regi/studyn_en.pdf [Accessed 3 June 2015]

EC 2010. $5^{\text {th }}$ Report on Economic, Social and Territorial Cohesion. Brussels, European Commission.

EhrLich, K. and LANG, T. 2012. Soziale Unternehmen und Initiativen in Deutschland-aufdem Weg zu einer neuen sozialen Ökonomie? [Online] Leipzig, Forum IfL. Available from: http://www.ssoar.info/ssoar/ bitstream/handle/document/31711/ssoar-2012-ehrlich_et_al-Soziale_Unternehmen_und_Initiativen_ in.pdf?sequence $=1$ [Accessed 9 June 2015]

Ehrlich, K., Kriszan, A. and LANG, T. 2012. Urban Development in Central and Eastern Europe - Between Peripheralization and Centralization? disP 189. (2): 77-92.

Eriksson, M. 2008. (Re)Producing a 'Peripheral' Region - Northern Sweden in the News. Geografiska Annaler, Series B 90. (4): 369-388.

EU 2011. Territorial Agenda of the European Union 2020. Towards an Inclusive, Smart and Sustainable Europe of Diverse Regions. [Online] Brussels, European Union. Available from: http://www.espon.eu/export/sites/default/Documents/Publications/Monitoring/Territorial MonitoringReport/ESPON_MONITORING_ REPORT.pdf [Accessed 9 June 2015]

Filipov, D. and Dorbritz, J. 2003. Demographic consequences of economic transition in countries of Central and Eastern Europe. Strasbourg, Council of Europe Publishing.

FinkA, M. 2007. Territorial Cohesion - Between Expectations, Disparities and Contradictions. In German Annual of Spatial Research and Policy 2007. Territorial Cohesion. Ed.: ScHolich, D. Berlin, Springer Verlag, 23-39.

FINKA, M. 2011. Evolving Framework for Regional Development and Spatial Planning in the New Regions of the EU. In Territorial Development, Cohesion and Spatial Planning. Eds.: Adams, N., Cotella, G. and Nunes, R. London, Routledge, 103-122.

FinKa, M., KLuVÁNKOVÁ-OravsKá, T. and OndrejIČKA, V. 2015. Concept of soft polycentric governance for fuzzy soft spaces as a challenge for Central European peripheral spaces. In Understanding Geographies of Polarization and Peripheralization. Eds.: Lang, T., Henn, S., Ehrlich, K. and Sgibnev, W. Basingstoke, Palgrave, 309-322.

FriedmanN, J. 1986. The World City Hypothesis. Development and Change 17. (1): 69-83.

Giddens, A. 1993. New Rules of Sociological Method. A positive critique of Interpretative Sociologies. Stanford, Stanford University Press.

GLÜCKLER, J. 2013. Knowledge, networks and space: Connectivity and the problem of non-interactive learning. Regional Studies 47. (6): 880-894.

Gorzelak, G. and GoH, C. (eds.) 2010. Financial Crisis in Central and Eastern Europe - from Similarity to Diversity. Warsaw, Wydawnictwo Naukowe Scholar.

Hudson, R. 2004. Conceptualizing economies and their geographies: spaces, flows and circuits. Progress in Human Geography 28. (4): 447-471.

Hudson, R. 2005. Economic Geographies. Circuits, Flows and Spaces. London, SAGE Publications.

JANsson, D. 2003. Internal orientalism in America: W.J. Cash's The Mind of the South and the spatial construction of American national identity. Political Geography 22. (3): 293-316.

Keating, M. 2008. A Quarter of a Century of the Europe of the Regions. Regional and Federal Studies 18. (5): 629-635.

Komlosy, A. 1988. An den Rand gedrängt: Wirtschaftsund Sozialgeschichte des oberen Waldviertels. Wien, Verlag für Gesellschaftskritik.

Komornicki, T. and Czapiewski, K. (eds.) 2006. Europa $X X I-14$. Core and peripheral regions in Central and Eastern Europe. Warsaw, Polish Academy of Sciences.

KRÄTKE, S. 2007. Metropolisation of the European Economic Territory as a Consequence of Increasing Specialisation of Urban Agglomerations in the Knowledge Economy. European Planning Studies 15. (1): 1-27.

Laclau, E. and Mouffe, C. 1985. Hegemony and Socialist Theory: Toward a Radical and Plural Democracy. London, Verso.

Lagendijk, A. and Lorentzen, A. 2007. Proximity, Knowledge and Innovation in Peripheral Regions. On the Intersection between Geographical and Organizational Proximity. European Planning Studies 15. (4): 457-466.

LANG, T. 2009. Institutional perspectives of local development in Germany and England: a comparative study about regeneration in old industrial towns experiencing decline. [Online] Potsdam, Universität Potsdam. Available from: http://opus.kobv.de/ubp/volltexte/2009/3734/ [Accessed 26 January 2015].

LANG, T. 2011. Regional development issues in Central and Eastern Europe: shifting research agendas from a focus on peripheries to peripheralisation? In Geography in Visegrad and Neighbour Countries. Eds.: Erôss, Á. and Karácsonyi, D. Budapest, Geographical Research Institute HAS, 57-64.

LANG, T. 2012a. Shrinkage, Metropolization and Peripheralization in East Germany. European Planning Studies 20. (10): 1747-1754.

LANG, T. 2012b. Conceptualising urban shrinkage in East Germany: understanding regional peripheralisation in the light of discursive forms of region building. In Peripherization: The Making of Spatial Dependencies and Social Injustice. Eds.: Naumann, M. and Fischer-TAhir, A. Heidelberg, Springer, 224-238.

LANG, T. 2016. Urban decline, resilience and change: Understanding how cities and regions adapt to so- 
cio-economic crises. In Cities in Crisis. Socio-Spatial Impacts of the Economic Crisis in Southern European Cities. Eds.: Knieling, J. and Othengrafen, F. London, Routledge. (Forthcoming)

Massey, D. 1993. Power-geometry and a progressive sense of place. In Mapping the Futures: Local Cultures, Global Change. Eds.: Bird, J., Curtis, B., Putnam, T. and Robertson, G. London, Routledge, 60-70.

Massey, D. 2009. Concepts of space and power in theory and in political practice. Documents d'Anàlisi Geogràfica 55. 15-26.

McCAnn, E.J. 2004. Urban Political Economy Beyond the 'Global City'. Urban Studies 41. (12): 2315-2333.

MCCARTHY, J. 2005. Rural geography: multifunctional rural geographies - reactionary or radical? Progress in Human Geography 29. (6): 773-782.

Miggelbrink, J. and Meyer, F. 2015. Lost in Complexity? Researching the Role of Socio-Spatial Ascriptions in the Process of Peripheralization. In Understanding Geographies of Polarization and Peripheralization. Eds.: Lang, T., Henn, S., Ehrlich, K. and Sgibnev, W. Basingstoke, Palgrave, 62-79.

Monfort, P. 2009. Regional Convergence, Growth and Interpersonal Inequalities across EU. Report Working Paper for Directorate General Regional Policy. [Online] Brussels, European Commission. Available from: http://ec.europa.eu/regional_policy/archive/ policy/future/pdf/9_monfort_final_formatted.pdf [Accessed 4 June 2015].

Nagy, E., Timár, J., Nagy, G. and Velekey, G. 2015. The Everyday Practices of the Reproduction of Peripherality and Marginality in Hungary. In Understanding Geographies of Polarization and Peripheralization. Eds.: Lang, T., Henn, S., Ehrlich, K. and Sgibnev, W. Basingstoke, Palgrave, 135-155.

North, D.C. 1990. Institutions, Institutional Change and Economic Performance. Cambridge, Cambridge University Press.

OECD 2014. How's Life in Your Region? Measuring Regional and Local Well-being for Policy Making. Paris, OECD Publishing. Available from: http://dx.doi.org/1 0.1787/9789264217416-en [Accessed 9 June 2015].

OECD 2015. In It Together: Why Less Inequality Benefits All. Paris, OECD Publishing.

Openshaw, S. 1984. The Modifiable Areal Unit Problem. Norwich, Geo Books.

Parnreiter, C. 2014. Global Cities and the Production of Uneven Development. In The Companion to Development Studies. $3^{\text {rd }}$ edition. Eds.: DesAI, V. and Potter, R. London, Routledge, 291-295.

Perrons, D. 2012. Regional performance and inequality: linking economic and social development through a capabilities approach. Cambridge Journal of Regions, Economy and Society 5. (1): 15-29.

Pierson, P. 2000. Increasing Returns, Path Dependence, and the Study of Politics. American Political Science Review 94. (2): 251-267.
Pike, A., Rodríguez-Pose, A. and Tomaney, J. 2007. What kind of local and regional development and for whom? Regional Studies 41. (9): 1253-1269.

Piketry, T. 2013. Le Capital au XXIe siècle. Paris, Le Seuil.

PoSCoPP 2015. Understanding New Geographies of Central and Eastern Europe. In Understanding Geographies of Polarization and Peripheralization. Eds.: Lang, T., Henn, S., Ehrlich, K. and Sgibnev, W. Basingstoke, Palgrave, 1-21.

RangmaA, G. 2015. Territorial Governance and Core-Periphery-Relations: The Implications of European Policy Concepts to Central and Eastern Europe. In Understanding Geographies of Polarization and Peripheralization. Eds.: LAng, T., Henn, S., Ehrlich, K. and Sgibnev, W. Basingstoke, Palgrave, 287-308.

Reimer, M., Getsimis, P. and Blotevogel, H. 2014. Spatial Planning Systems and Practice in Europe. A comparative perspective. In Spatial Planning Systems and Practices in Europe: A Comparative Perspective on Continuity and Changes. Eds.: Reimer, M., Getsimis, P. and Blotevogel, H. London, Routledge, 1-20.

Sassen, S. 1991. The Global City: New York, London, Tokyo. Princeton, Princeton University Press.

Sellers, J.M. 2002a. Governing from below: Urban regions and the global economy. Cambridge, Cambridge University Press.

Sellers, J.M. 2002b. The Nation-State and Urban Governance. Toward Multilevel Analysis. Urban Affairs Review 37. (5): 611-641.

Servillo, L. 2010. Territorial cohesion discourses: Hegemonic strategic concepts in European Spatial Planning. Planning Theory and Practice 11. (3): 397-416.

Shearmur, R. 2012. Are cities the font of innovation? A critical review of the literature on cities and innovation. Cities 29. 9-19.

Sмiтh, A. and Timár, J. 2010. Uneven transformations: Space, economy and society 20 years after the collapse of state socialism. European Urban and Regional Studies 21. (3): 115-125.

Smith, A., Stenning, A., Rochovská, A. and Światek, D. 2008. The emergence of a working poor: Labour markets, neoliberalisation and diverse economies in post-socialist cities. Antipode 40. (2): 283-311.

Sotarauta, M., Horlings, L. and Liddle, J. (eds.) 2012. Leadership and Change in Sustainable Regional Development. London, Routledge.

Steinführer, A. and HaAse, A. 2007. Demographic Change as Future Challenge for Cities in East Central Europe. Geografiska Annaler B. 89. (2): 183-195.

Stenning, A., Smith, A., RochovsKá, A. and SwiAteK, D. 2010. Domesticating Neo-Liberalism: Spaces of Economic Practice and Social Reproduction in PostSocialist Cities. Malden, Wiley-Blackwell. 
Stoker, G. 1998. Governance as theory: five propositions. International Social Science Journal 50. (155): 17-28.

Tímár, J., Nagy, E., Nagy, G., Velkey, G., Kugler, J. and Duray, B. 2012. Társadalomtudósok a " periférián" (Social scientists on the "periphery"). Tér és Társadalom 26. (3): 151-163.

TsEnKova, S. 2006. Beyond transitions: Understanding urban change in post-socialist cities. In The urban mosaic of post-socialist Europe. Eds.: Tsenkova, S. and Budic-Nedovic, Z. Heidelberg, Physica-Verlag, 21-50.

Varró, K. and LagendiJK, A. 2013. Conceptualizing the Region - In What Sense Relational? Regional Studies 47. (1): 18-28.
VirkKala, S. 2007. Innovation and Networking in Peripheral Areas - a Case Study of Emergence and Change in Rural Manufacturing. European Planning Studies 15. (4): 511-529.

Waterhout, B., Othengrafen, F. and Sykes, O. 2013. Neo-liberalization Processes and Spatial Planning in France, Germany, and the Netherlands: An Exploration. Planning Practice and Research 28. (1): 141-159.

Willett, J. 2010. Why is Cornwall So Poor? Narrative, Perception and Identity. PhD Thesis. [Online] Exeter, University of Exeter. Available from: https://ore. exeter.ac.uk/repository/handle/10036/104835 [Accessed 9 June 2015]. 


\title{
Minsk and Budapest, the two capital cities
}

\author{
Edited by
}

\author{
LÁsZló Jeney and DÁvid Karácsonyi
}

\begin{abstract}
Department of Economic Geography and Futures Studies, Corvinus University of Budapest; Geographical Institute RCAES HAS; Faculty of Geography, Belarusian State University; Institute for Nature Management, National Academy of Sciences of Belarus
\end{abstract}

\author{
Budapest, 2015. 194 p.
}

While Budapest used to be the bridge between the West and East in Central Europe, Minsk seems to be in a similar role between the Russian and the EU-Polish influence zones. It means that both capitals are situated on the frontiers between the Euro-Atlantic and the Euro-Asian macro regions. Besides their situations, their similarity in size renders the comparison and the cooperation obvious to proceed. This book is based

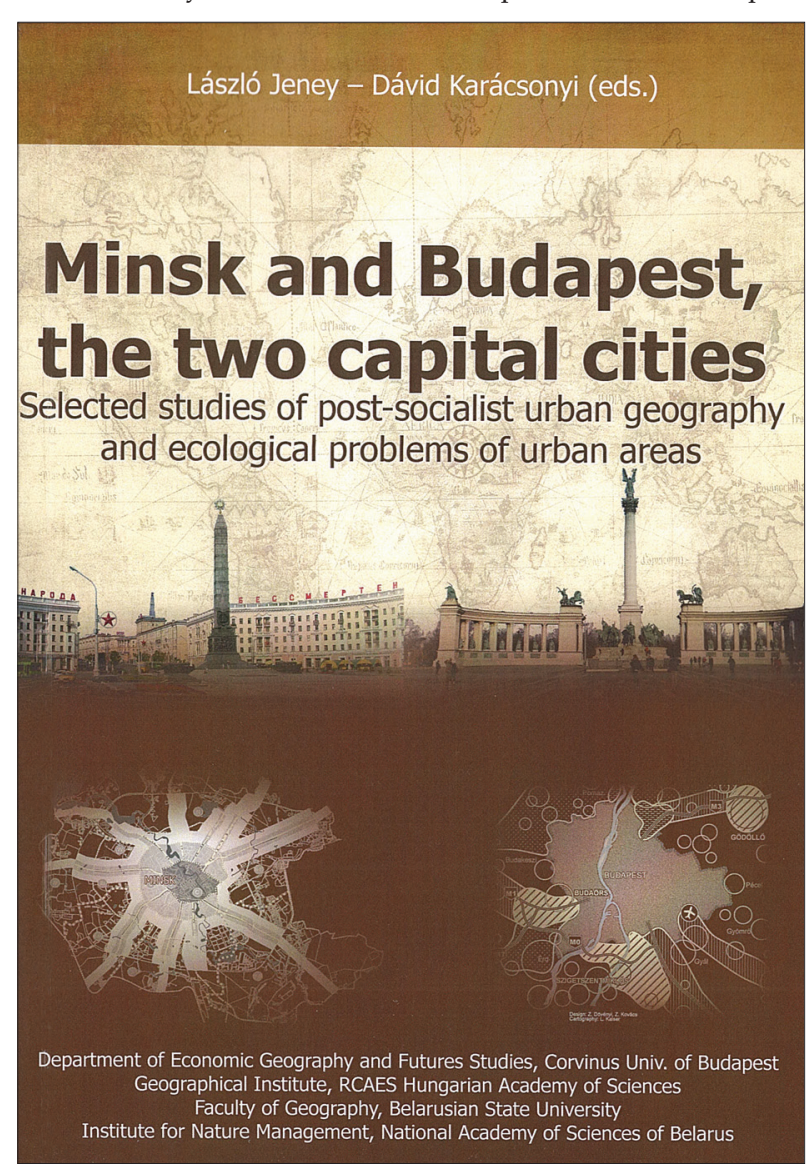

on the mutual co-operation of Hungarian and Belarussian geographers and gives a scientific outlook not only on the socioeconomic development of the two cities but on the urban climate, environment and ecology as well. Hungarian authors of the book introduce Budapest as a Central European metropolis with its historical trajectories and the results of the post-socialist transformation. They also demonstrate the main features of large housing estates and the results of their rehabilitation. Authors from Belarus show the major issues of spatial structure planning of Minsk in a similar context, describing the past and the present changes taking place in the spatial structure of the metropolis. The integrated assessment of the state of urban environment in Minsk is examined also focusing on the ecological frame of the environmental planning in urban agglomerations. The volume serves as a good starting point of a fruitful co-operation between Belarussian and Hungarian geographers dealing with a social and physical urban environment, the state of which deserves extra attention especially in East Central and Eastern Europe.

Copies are available: Library, Geographical Institute of RCAES HAS, H-1112 Budapest, Budaörsi u. 44. E-mail: magyar.arpad@ csfk.mta.hu 